\title{
STRATEGI DAN SKALA KESANTUNAN TINDAK DIREKTIF MAHASISWA RIAU DI LINGKUNGAN MASYARAKAT BERLATAR BELAKANG BUDAYA JAWA
}

\author{
Puji Lestari dan Harun Joko Prayitno \\ Program Studi Pendidikan Bahasa Indonesia \\ Fakultas Kegururan dan Ilmu Pendidikan \\ Universitas Muhammadiyah Surakarta \\ lestariji@gmail.com \\ harunjpums@yahoo.com
}

\begin{abstract}
This research aims to expose strategy and scale of politeness in Riau students directive speech surrounded by Javanese culture, also its implications on language learning in manners in high school. This is a qualitative descriptive research. The data are in the form of directive speech either in formal or informal. The data source includes the activities of 15 Riau students of UMS, UNS, and IAIN. The data gathering techniques includes refering, recording, and taking notes. Data analysis methods in this research includes pragmatics comparison wether intralingual and extralingual. The interpretation of directive speech form is done by reffering to Prayitno's work, while the analysis of politeness scale is based on Lakoff's model. The results showed that (1) Riau students are much prefer to use indirect strategy when they are communicating with Javanese society $(66,70 \%: 33,30 \%)$. (2) The analysis of politeness scale refers to the results of the politeness strategy category in terms of politeness levels low, medium, and fine. The combination of politeness strategy of Riau students has a low level of politeness with comparison 47\%: 23\%: $30 \%$. Total data on the scale of politeness in directive speech is low for as many as 14 data, while the level of politeness are as many as 7 data, and the level of good politeness is as much as 9 data. (3) The implications of this research on language learning with manners in high school can be used as learning materials. In the 2013 curriculum, it is stated that the core competencies-2 (KI-2) of social attitude of class $X, X I$, and XII demands students to able to use the Indonesian language with manners while KTSP curriculum focused at speaking skills. Language learning can be fun if students and teachers are able to use the language more politely.
\end{abstract}

Keywords: implications, scales, and politeness strategy for the directive speech

\begin{abstract}
ABSTRAK
Penelitian ini bertujuan memaparkan strategi dan skala kesantunan tindak direktif mahasiswa Riau di lingkungan masyarakat berlatar belakang budaya Jawa, serta implikasinya terhadap pembelajaran bahasa secara santun di SMA. Jenis penelitian ini termasuk deskriptif kualitatif. Data penelitian berupa satuan lingual tindak tutur direktif, baik dalam suasana formal maupun nonformal di sekitar wilayah Surakarta. Adapun sumber data meliputi aktivitas mahasiswa Riau dari UMS, UNS, dan IAIN sebanyak 15 orang. Teknik pengumpulan data menggunakan teknik simak, rekam, dan catat. Analisis data menggunakan metode padan pragmatik, baik intralingual dan ekstralingual. Interprestasi perwujudan strategi tindak direktif dilakukan dengan
\end{abstract}


cara kerja analisis mengacu dari Prayitno, sedangkan analisis skala kesantunan berdasarkan model Lakoff. Hasil penelitian menunjukkan bahwa (1) mahasiswa Riau ketika bertutur dengan masyarakar berlatar belakang budaya Jawa lebih banyak menggunakan strategi tak langsung daripada langsung dengan perbandingan $(66,7 \%$ : 33,3\%). (2) Analisis skala kesantunan mengacu pada hasil kategori strategi kesantunan yang ditinjau dari tingkat kesantunan rendah, sedang, dan baik. Kombinasi strategi kesantunan dengan skala kesantunan mahasiswa Riau memiliki tingkat kesantunan yang rendah dengan perbandingan (47\%:23\%:30\%). Total data pada skala kesantunan direktif berdasarkan strategi langsung dan tak langsung untuk tingkat kesantunan rendah sebanyak 14 data, tingkat kesantunan sedang sebanyak 7 data, dan tingkat kesantunan baik sebanyak 9 data. (3) Implikasi penelitian terhadap pembelajaran bahasa secara santun di SMA dapat dijadikan sebagai bahan ajar, yaitu pada kurikulum 2013 tampak bahwa kompetensi inti-2 (KI-2) untuk sikap sosial dari kelas X, XI, dan XII yang menuntut siswa mampu menggunakan bahasa Indonesia dengan santun pada proses pembelajaran dan kurikulum KTSP tampak pada standar kompetensi keterampilan berbicara. Pembelajaran menjadi menyenangkan jika siswa dan guru dapat menggunakan bahasa yang santun.

Kata Kunci: implikasi, skala, stategi kesantunan tindak direktif

\section{PENDAHULUAN}

Bahasa dan budaya lokal memberi peran yang signifikan dalam kesantunan berbahasa di Indonesia sehingga bisa membentuk salah satu wujud karakter yang positif. Berdasarkan fakta kebahasaan, pemakaian bahasa Indonesia yang santun dipengaruhi oleh entitas bahasa daerah dan budayanya (Hendaryan, 2011:1). Jadi, sesuatu yang dianggap santun oleh kultur tertentu belum tentu dianggap santun oleh kultur lain. Hal tersebut dikarenakan bahwa pemakaian bahasa ditentukan oleh konteks. Wijana (dalam Nadar, 2009:4) menyatakan bahwa pragmatik mengkaji makna yang terikat dengan konteks.

Permasalahan dalam penelitian ini adalah fenomena kultur antara budaya Riau dengan budaya Jawa. Peran pelaku yakni $P n$ dan $M t$ bersemuka untuk tetap bereksistensi yang bertujuan menghasilkan tuturan yang baik. Alasan diadakan penelitian ini karena baik secara sadar maupun tidak sadar pertuturan yang terjadi antara mahasiswa Riau dengan masyarakat Jawa menimbulkan konflik batin atau psikologis yang masih belum terungkap antara mahasiswa Riau dan masyarakat berlatar belakang budaya Jawa. Selanjutnya, alasan pemilihan mahasiswa Riau sebagai objek penelitian karena tuturan yang disampaikan mahasiswa Riau di lingkungan masyarakat berlatar belakang budaya Jawa cenderung menggunakan tuturan tindak direktif dan sekaligus sebagai pembanding tuturan di lingkungan masyarakat berlatar belakang budaya Jawa.

Pada dasarnya mahasiswa Riau menggunakan bahasa Melayu, tetapi karena ada yang berasal dari suku Ocu, bahasa daerah Ocu pun sering digunakan. Bahasa Ocu dalam kosa katanya banyak kemiripan dengan bahasa Minang Sumatra Barat, tetapi dalam vokal dan dialek sangat kental dengan Melayu dan menjadikan bahasa Ocu khas. Mahasiswa Riau mengikuti kegiatan forum daerah (FORDA) mahasiswa dan organisasi daerah (ORDA) mahasiswa di wilayah Surakarta baik dari UMS, UNS, maupun IAIN. Organisasi IKPMRS atau Ikatan Keluarga Pelajar Mahasiswa Riau Surakarta merupakan sebutan untuk komunitas mahasiswa Riau yang menempuh pendidikan di Surakarta. Kegiatan yang yang dilakukan, seperti festival budaya UNS, festival budaya UMS, grebek Sudira, festival Jenang, CFD bareng RRI, penggalangan 
dana untuk bencana, baksos, diskusi ilmiah, makrab atau silahturahmi, dan kegiatan dengan masyarakat di perkampungan. Hal tersebut membuat terjadinya interaksinya mahasiswa Riau dengan masyarakat Jawa yang memiliki latar belakang budaya yang berbeda selain beraktivitas kuliah.

Mahasiswa Riau dipandang sebagai orang pendatang di lingkungan budaya Jawa. Masyarakat Jawa sangat mengedepankan 'rukun' sehingga terkenal dengan ungkapannya rukun agawe santosa 'kerukunan merupakan modal kesentosaan' dengan cara menunjukkan sikap yang tenang dan tidak mengumbar emosi secara berlebihan (Prayitno, 2011:37). Adapun mahasiswa Riau lebih terbuka dan tidak menyukai basa-basi. Perbedaan latar belakang ini menarik untuk diteliti. Misalnya dari tuturan sapaan abang/ uda/ ocu (Riau:'abang') dengan mas (Jawa:'abang') dan penggunaan partikel do, tio, tu (Riau) dengan to,we, po (Jawa). Hal sederhana tersebut bisa saja menimbulkan perbedaan dalam pemaknaan sopan santun saat berkomunikasi. Contohnya pada tuturan direktif memerintah yang ditujukan kepada seorang laki-laki lebih tua (Jawa) saat diskusi ilmiah di kampus, "Eh bang ambilkan pena tu aa!".

Adapun strategi yang digunakan adalah strategi langsung tanpa basa-basi yang menunjukkan tuturan menjadi kurang sopan. Penggunaan kata sapaan "bang" belum sesuai konteks karena lawan tutur adalah orang Jawa yang biasanya menggunakan kata sapaan Mas sehingga menunjukkan jarak sosial menjadi jauh. Selain itu, partikel $t u$ dianggap sebagai partikel tidak sopan menurut penutur Melayu karena partikel $t u$ menunjukkan 'keharusan' dan hanya ditujukan kepada lawan tutur yang lebih muda. Oleh karena itu, berdasarkan skala kesantunan, ini tergolong tidak santun apabila dituturkan kepada orang Jawa sehingga melanggar skala keformalitasan. Skala kesantunan merupakan peringkat kesantunan, mulai dari yang tidak santun sampai dengan paling santun (Chaer, 2010:63). Variasi dari strategi yang digunakan mahasiswa Riau di lingkungan budaya masyarakat inilah yang menarik dikaji pertuturannya sehingga kesantunan berbahasa direktifnya dapat diungkapkan.

Rahardi (2005:10) menyatakan bahwa studi kesantunan berbahasa dapat menopang lancarnya komunikasi dan interaksi lintas budaya. Penelitian ini bisa menjadi referensi agar mahasiswa Riau bisa menyesuaikan diri di lingkungan masyarakat budaya Jawa. Analisis data penelitian ini dilakukan untuk menemukan masalah-masalah yang berkaitan dengan kesantunan direktif pada mahasiswa Riau di lingkungan masyarakat berlatar belakang budaya Jawa yang juga dikaitkan pada implikasi terhadap pembelajaran bahasa secara santun di SMA. Jadi, perlu dikaji dalam bentuk penelitian dari penggunaan strategi bertutur dikaitkan dengan skala-skala pragmatik sebagai alat pengukur tingkat kesantunan.

\section{METODE PENELITIAN}

Jenis penelitian ini adalah penelitian deskriptif kualitatif. Data penelitian berupa satuan lingual tindak tutur direktif baik dalam suasana formal maupun nonformal di sekitar wilayah Surakarta. Adapun sumber data meliputi aktivitas mahasiswa Riau dari UMS, UNS, dan IAIN sebanyak 15 orang. Data penelitian diambil sebanyak 30 data.

Teknik pengumpulan data dalam penelitian ini adalah metode simak, rekam, dan metode catat. Metode simak merupakan metode dalam penyajian data yang dilakukan dengan cara menyimak penggunaan atau pemakaian bahasa (Rahardi, 2005:15). Metode yang digunakan dalam metode simak adalah teknik sadap sebagai dasarnya dan teknik simak bebas libat cakap serta teknik catat sebagai teknik lanjutan. Pengumpulan data dengan teknik sadap dilakukan dengan cara menyimak penggunaan bahasa tindak direktif mahasiswa Riau di lingkungan masyarakat berbudaya Jawa daerah sekitar wilayah Surakarta. Kemudian, dilanjutkan teknik simak bebas libat cakap yang peneliti tidak terlibat dalam pertuturan, tetapi peneliti merekam pertuturan antara mahasiswa Riau dengan masyarakat berbudaya Jawa. Hasil rekaman 
dilanjutkan dengan klasisifikasi data ditinjau dari pemarkah lingual dan noningual. Klasifikasi tersebut dilakukan untuk mendapatkan jenis atau tipe data yang tepat dan cermat. Selanjutnya, data dapat dianalisis pada tahap selanjutnya.

Teknik analisis data dalam penelitian ini dilakukan dengan metode padan pragmatik, yaitu metode yang digunakan untuk mengkaji dan menentukan identitas satuan lingual tertentu dengan memakai alat penentu yang berada di luar bahasa (Subroto dalam Prayitno, 2010:33). Sudaryanto (1993:15) menyebutnya dengan metode pragmatis dengan alat penentu mitra wicara. Data yang terkumpul dan sudah diklasifikasikan berdasarkan tipe-tipe tertentu dianalisis dengan teknik padan intralingual dan ekstralingual. Interprestasi perwujudan strategi tindak tutur direktif dilakukan dengan cara kerja analisis pragmatik mengacu pada analisis derajat keterancaman potensial dari Prayitno (2011:129-136). Skala peringkat kesantunan bertutur direktif dianalisis mengacu pada model Lakoff (dalam Chaer, 2010:63-64), yaitu (a) skala formalitas (formality scale); (b) skala ketidaktegasan atau pilihan (optionally scale), dan (c) skala kesekawanan.

\section{HASIL DAN PEMBAHASAN}

Penelitian ini mengkaji 30 data dari hasil temuan strategi kesantunan berkategori yang dikaitkan dengan skala kesantunan tindak tutur direktif mahasiswa Riau di lingkungan masyarakat berlatar belakang budaya Jawa. Selanjutnya, dikaitkan dengan implikasinya terhadap pembelajaran bahasa secara santun di SMA. Berdasarkan analisis data, ditemukan beberapa hasil dan pembahasan.

\section{Strategi Kesantunan Direktif}

Interprestasi perwujudan strategi tindak tutur direktif dilakukan dengan cara kerja analisis pragmatik mengacu pada analisis derajat keterancaman potensial dari Prayitno (2011:129136), yaitu strategi langsung dan strategi tak langsung. Setiap strategi kesantunan direktif diklasifikasikan berdasarkan kategori masing-masing. Berikut contoh analisis dari strategi kesantunan direktif langsung dan tak langsung.

\section{a. Strategi Kesantunan Direktif Langsung}

Strategi kesantunan direktif langsung berarti mengungkapkan makna dan maksud tuturan berdasarkan apa yang diungkapkan sehingggat mitra tutur $(M t)$ langsung mengetahui makna dan maksud tuturan dari $P n$ (penutur). Temuan dari penelitian ini menghasilkan strategi kesantunan direktif langsung berkategori, yakni mengajak, meminta, memerintah, mengingatkan, melarang, dan menyilakan. Contoh hasil analisis tampak pada (1) yang menggunakan strategi langsung berkategori mengajak.

Cuplikan eksplikatur berikut pada contoh (1) tampak bahwa mencapai maksud KD mengajak meskipun tidak ditandai oleh bentuk eksplisit saya ajak tetapi pemarkah lingualnya berupa Vp implisit mari. Maksud contoh (1) berbentuk imperatif ajakan, yakni Pn mengajak $M t$ agar mau mencicipi jenang buatan mahasiswa Riau. Pada contoh (1), tampak bahwa mahasiswa Riau melakukan strategi langsung untuk menuju maksud mengajak.

Mahasiswa Riau Universitas Muhammadiyah Surakarta

Eksplikatur : Mari yang mau asem podeh lomak lai! (Mari yang mau jenang asam pedas rasanya enak sekali!) 
$\underline{\text { TKD }}$

Pemarkah Lingual : Vp implisit "mari"

Penanda Nonlingual : Aktivitas festival jenang saat pembagian jenang

Situasi yang sangat tenang.

$P n$ mengajak $M t$ untuk mencicipi jenang buatan Pn.

$M t$ masih memilih-milih jenang yang akan dicicipi.

$P n$ ingin jenangnya banyak yang akan mencicipi.

Topik : ajakan mencicipi jenang

Status sosial $\quad: P n$ mahasiswa semester 6, laki-laki, usia 20 tahun.

Mt seorang pengunjung festival jenang, perempuan, usia 30 tahun.

Implikatur $\quad: P n$ ingin $M t$ mau mencicipi jenang buatan mahasiswa Riau, meskipun sudah banyak yang mencicipi jenangnya. Pn mempromosikan jenang dengan sebutan "asam podeh" khas Riau yang rasanya enak.

Maksud TKD $\quad$ : Ajakan $P n$ untuk mencicipi jenang Riau dengan khas rasa asam pedas.

Maksud sub-TKD : Ajak

\section{b. Strategi Kesantunan Direktif Tak Langsung}

Strategi tindak direktif tak langsung di dalam penelitian ini adalah tuturan tindak direktif yang memiliki modus maksud yang berbeda dari tuturan yang disampaikan. Temuan penelitian ini menghasilkan strategi kesantunan direktif berkategori seperti meminta, memerintah, mendesak, memohon, menyindir, mengharap, merayu, membujuk, dan memberi saran. Contoh (2) berikut menggunakan strategi tak langsung berkategori memerintah.

Contoh (2) menunjukkan adanya pengubahan fungsi jenis tuturan, yakni untuk menyatakan perintah digunakan tuturan berita sehingga fungsi tidak sejalan dengan maksud. Tidak ada pemarkah lingual yang mengandung perintah. Namun, jika pemarkah lingual dikaitkan dengan penanda nonlingual dan implikatur menunjukkan Pn memerintah Mt untuk mengambil sesuatu. Contoh (2) menunjukkan bahwa Pn memerintah Mt untuk melayani pesanannya berupa es teh dan dua tempe.

Mahasiswa Riau Universitas Muhammadiyah Surakarta

Eksplikatur $\quad:$ Bu, tempe dua sama es teh satu.

$\underline{\text { TKD }}$

Pemarkah Lingual : Intonasi berita.

Penanda Nonlingual : Suasana ketika di warung makan, $P n$ memesan makanan dan minuman sambil mencari tempat duduk. $M t$ sedang sibuk melayani pembeli lainnya dan hanya melirik $P n$. $P n$ lebih muda daripada $M t P n$ berjenis kelamin laki-laki dan $M t$ berjenis 
Status social

Implikatur

Maksud TKD

Maksud sub-TKD kelamin perempuan. $M t$ merasa kecewa karena $P n$ tidak sabar menunggu

: Mahasiswa semester 4 berusia 19 tahun, $P n$ laki-laki, Mt perempuan, penjual makanan.

: $P n$ ingin diambilkan pesanannya meski $M t$ sedang sibuk Lirikan $M t$ sebagai respon dari perintah $P n$

: Memerintah $M t$ untuk mengambil pesanan es teh dan dua tempe. Perintah

Berdasarkan hasil temuan, penggunaan strategi kesantunan direktif langsung berkategori ditemukan sebanyak 11 data. Kategori mengajak terdapat 2 data, yaitu data 06 . Kategori meminta terdapat 3 data, yaitu data 20, 22, dan 28. Kategori memerintah terdapat 2 data, yaitu data 04 dan data 08 . Selanjutnya, kategori mengingatkan terdapat 1 data, yakni data 10 . Kategori melarang terdapat 3 data, yakni data 18 , 21, dan 29. Kategori menyilakan terdapat 1 data berupa data 19 .

Sementara itu, penggunaan strategi kesantunan direktif tak langsung berkategori ditemukan sebanyak 19 data berkategori, yaitu kategori meminta terdapat 4 data, yaitu data 03, 05, 25, dan 26. Kategori memerintah terdapat 2 data, yaitu data 01 dan data 23. Kategori mendesak terdapat 3 data, yakni data 02, 13, dan 17. Kategori memohon terdapat 2 data, yakni data 07 dan 15. Kategori menyindir terdapat 2 data, yakni data 06 dan 12. Kategori mengharap terdapat 3 data, yakni data 14, 24, dan 27. Kategori merayu terdapat 1 data, yaitu data 09. Kategori membujuk terdapat 1 data, yaitu data 10 serta kategori memberi saran terdapat 1 , yaitu data 30. Hasil temuan penelitian ini menunjukkan bahwa mahasiswa Riau ketika bertutur dengan masyarakar berlatar belakang budaya Jawa lebih banyak menggunakan cara-cara tak langsung daripada cara langsung. Perbandingan antara strategi tak langsung dengan langsung $(63,3 \%$ : $36,7 \%)$.

Penggunaan strategi langsung oleh mahasiswa Riau menunjukkan bahwa mahasiswa Riau berpotensi lebih banyak menggunakan strategi langsung dalam situasi tuturan untuk mencapai maksud melarang dan meminta (10\%) daripada mengajak, mengingatkan, dan menyilakan (3,30\%). Temuan ini menggambarkan bahwa mahasiswa Riau belum begitu berani menjalin hubungan kekerabatan dengan cara mengajak, mengingatkan, dan menyilakan di lingkungan masyarakat berlatar belakang budaya Jawa. Adapun penggunaan strategi kesantunan direktif tak langsung tampak bahwa untuk mencapai maksud meminta $(13,30 \%)$ lebih berpotensi digunakan oleh mahasiswa Riau di lingkungan masyarakat berlatar belakang budaya Jawa daripada membujuk, memberi saran (3,30\%). Temuan ini menunjukkan bahwa mahasiswa Riau belum berani untuk berusaha menggugah hati, meyakinkan, dan memberi anjuran atau pendapat terhadap masyarakat berlatar belakang budaya Jawa. Hasil penelitian dari strategi kesantunan direktif dapat dilustrasikan melalui tabel 1 dan gambar 1 berikut.

Dengan adanya hasil temuan di bawah ini ada beberapa penelitian yang juga pernah meneliti tentang strategi kesantunan direktif. Hal tersebut tampak dari adanya persamaan dan perbedaan hasil penelitian. Adapun persamaan dan perbedaan antara penelitian ini dengan penelitian relevan sebelumnya, seperti yang dilakukan Maros (2011), Pramuaniati dan Eviyanti (2012), Sukma (2012), Andianto (2012), Sulistyono, dkk. (2013), Anwari (2013), Bacha (2012), Peng (2014), Gu (2014), Welvi (2015), Mu (2015), dan Aliakbari (2015). Keduabelas penelitian tersebut, penelitian yang mendekati dengan penelitian ini adalah penelitian yang mengkaji penggunaan strategi kesantunan direktif langsung dan tak langsung yang diteliti oleh Maros (2011), Andianto (2012), Sulistyowati, dkk. (2013), Anwari (2013), dan Gu (2015). 
Penelitian Pramuaniati dan Eviyanti(2012), Sukma, dkk. (2012), dan Welvi(2014) memiliki kesamaan yang menghasilkan penelitian jenis strategi kesantunan dengan karakteristik masingmasing, yaitu (1) strategi bertutur terus terang tanpa basa-basi, (2) strategi bertutur terus terang (3) strategi bertutur terus terang dengan basa-basi, dan (4) strategi bertutur secara samarsamar. Hal tersebut menunjukkan bahwa adanya variasi penggunaan strategi kesantunan dalam penelitian. Oleh karena itu, penelitian tersebut masih memiliki keterkaitan dengan penelitian ini yang mengkaji startegi kesantunan langsung dan tak langsung.

Sementara itu, penelitian Peng (2014), Mu (2015), dan Aliakbari (2015) mengkaji strategi bertutur beracuan strategi kesantunan positif dan strategi kesantunan negatif, sedang penelitian ini tidak berfokus pada kesantunan positif dan negatif. Terakhir dari penelitian Bacha (2012) yang memiliki jenis strategi kesantunan yang berbeda dengan penelitian ini. Namun, penelitian Bacha juga menunjukkan variasi dari strategi kesantunan menggunakan, yaitu strategi kolaborasi, mendukung guru, dan memberikan kontribusi untuk interaksi kelas, sedangkan mahasiswa laki-laki menyukai strategi yang bersikap menantang.

Tabel 1

Strategi Kesantunan Direktif Mahasiswa Riau di Lingkungan Masyarakat Berlatar Belakang Budaya Jawa

\begin{tabular}{llccr}
\hline \multicolumn{1}{c}{ Jenis } & \multicolumn{1}{c}{ Kategori } & Frekuensi & $\mathbf{\%}$ & $(6)$ \\
Strategi & Mengajak & 1 & $3,3 \%$ & $(20),(22),(28)$ \\
Kesantunan & Meminta & 3 & $10 \%$ & $(8),(4)$ \\
Direktif & Memerintah & 2 & $6,7 \%$ & $(10)$ \\
Langsung & Melarang & 1 & $3,3 \%$ & $(18),(21),(29)$ \\
& Menyilakan & 3 & $10 \%$ & $(19)$ \\
Subtotal & & 1 & $3,3 \%$ & $(3),(5),(25),(26)$ \\
& Meminta & 11 & $36,7 \%$ & $(1),(23)$ \\
Strategi & Memerintah & 4 & $13,3 \%$ & $(2),(13),(17)$ \\
Kesantunan & Mendesak & 2 & $6,7 \%$ & $(7),(15)$ \\
Direktif Tak & Memohon & 3 & $10 \%$ & $(16),(12)$ \\
Langsung & Menyindir & 2 & $6,7 \%$ & $(14,(24),(27)$ \\
& Mengharap & 2 & $6,7 \%$ & $(9)$ \\
& Merayu & 3 & $10 \%$ & $(10)$ \\
Subtotal & Membujuk & 1 & $3,3 \%$ & $(30)$ \\
Jumlah Total & Memberi saran & 1 & $3,3 \%$ & \\
\hline & & 1 & $3,3 \%$ & $\mathbf{6 3 , 3 \%}$ \\
\end{tabular}

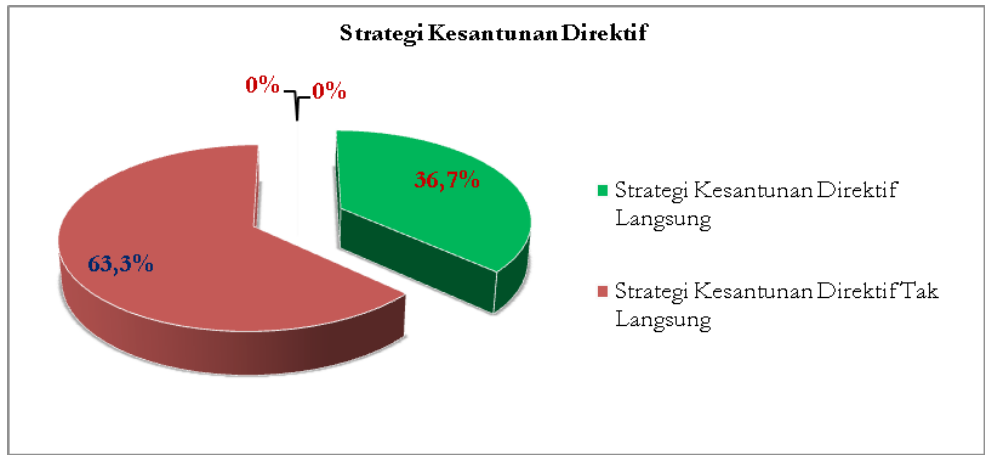

Gambar 1

Strategi Kesantunan Direktif Mahasiswa Riau di Lingkungan Masyarakat Berlatar Belakang Budaya Jawa 


\section{Skala Kesantunan Direktif}

Penentuan peringkat atau level kesantunan suatu tuturan dapat ditentukan derajatnya dengan mempertimbangkan skala-skala kesantunan. Adapun skala kesantunan yang digunakan dalam penelitian ini mengacu pada skala kesantunan Lakoff. Skala peringkat kesantunan bertutur direktif dianalisis mengacu pada model Lakoff (dalam Chaer, 2010: 63-64), yaitu: (a) skala formalitas (formality scale); (b) skala ketidaktegasan atau pilihan (optionally scale), dan (c) skala kesekawanan.

Skala formalitas dinyatakan bahwa agar para $P n$ dan $M t$ dalam berkomunikasi merasa nyaman dan tidak merasa ada paksaan atau tidak boleh terkesan angkuh. Pertuturan harus saling menjaga keformalitasan dan menjaga jarak yang sewajarnya dan sealamiah mungkin. Skala ketidaktegasan atau skala pilihan dinyatakan dengan adanya pilihan-pilihan dalam bertutur yang harus diberikan kepada kedua belah pihak sehingga tercipta rasa nyaman dan tidak boleh pertuturan tampak kaku. Skala kesekawanan menunjukkan sikap yang ramah dan selalu mempertahankan persahabatan. Rasa persahabatan dalam skala kesekawanan juga memperhitungan kontes dan jarak sosialnya antara $P n$ dengan $M t$.

Berdasarkan analisis 30 data, analisis skala kesantunan mengacu pada hasil kategori strategi kesantunan yang ditinjau dari tingkat kesantunan rendah, sedang, dan baik. Kombinasi strategi kesantunan dengan skala kesantunan yang digunakan mahasiswa Riau di lingkungan masyarakat berlatar belakang budaya Jawa dapat dikemukakan bahwa mahasiswa Riau memiliki tingkat kesantunan yang rendah dengan perbandingan (47\%:23\%:30\%). Total data pada skala kesantunan direktif berdasarkan strategi langsung dan tak langsung untuk tingkat kesantunan rendah sebanyak 14 data, tingkat kesantunan sedang sebanyak 7 data, dan tingkat kesantunan baik sebanyak 9 data. Dari uraian diatas dapat dipetik bahwa mahasiswa Riau di lingkungan masyarakat berlatar belakang budaya Jawa masih memerlukan bimbingan bernilai positif dan santun agar tercipta kerukunan dan keharmonisan.

\section{a. Skala Kesantunan Direktif Berdasarkan Strategi Langsung}

Skala kesantunan direktif berdasarkan strategi langsung pada tingkat kesantunan rendah terdapat 8 data, yaitu data 06 kategori mengajak, data 20 dan 28 kategori meminta, data 04 dan 08 kategori memerintah, data 18,21, dan 29 kategori melarang. Adapun pada tingkat kesantunan sedang tidak ditemukan pada strategi langsung. Sementara itu, pada tingkat kesantunan yang baik terdapat 3 data, yaitu data 22 kategori meminta, data 10 kategori mengingatkan, dan data 19 kategori menyilakan.

Cuplikan karakteristik skala kesantunan oleh mahasiswa Riau di lingkungan masyarakat berlatar belakang budaya Jawa pada contoh (3) menggunakan strategi langsung kategori meminta memiliki tingkat kesantunan yang rendah sebagai berikut.

Tuturan (3) : Pinjem pulpen kau dululah!

Konteks : Tuturan terjadi saat rapat festival harmoni UNS. Pn tidak membawa pena untuk presensi rapat sehingga meminjam pulpen kepada $M t$. Mt membawa pena. $P n$ sebaya dengan $M t$.

Berdasarkan skala formalitas, tuturan (3) terasa memaksa $M t$. Tuturan tampak bernada memaksa, seperti kau dululah sehingga terkesan angkuh. Semakin tuturan tidak memaksa maka semakin santun sebuah tuturan itu. Faktor usia yang sama antara $P n$ dengan $M t$ tidak menjamin sebuah tuturan tetap santun, karena $P n$ dengan $M t$ baru saling mengenal saat pelaksanaan festival harmoni di UNS. Jadi, disimpulkan tuturan (20) masih berada pada skala kesantunan yang rendah. 
Skala ketidaktegasan atau pilihan pada contoh (3) menunjukkan bahwa Pn belum leluasa memberikan berbagai pilihan di dalam tuturan. Tuturan (3) tampak memberikan satu pilihan kepada $M t$ agar meminjamkan pulpennya kepada $M t$. Dengan kata lain, $M t$ tidak mempunyai pilihan selain meminjamkan. Tuturan tersebut dapat menimbulkan kesan angkuh dan memaksa sehingga dapat membuat $M t$ tidak nyaman. Oleh karena itu, tuturan (3) memiliki skala kesantunan yang rendah.

Berdasarkan skala kesekawanan, semakin tuturan mempertahankan sikap persahabatan maka semakin santun. Sebaliknya, semakin rendah sikap mempertahankan persahabatan, maka semakin rendah tingkat kesantunan sebuah tuturan. $P n$ dengan $M t$ adalah teman sebaya, tetapi jarak sosial keduanya belum dikatakan "dekat" karena baru saling mengenal beberapa hari di acara festival harmoni. Tuturan (3) belum menunjukkan sikap yang ramah kepada $M t$, apalagi $P n$ tidak memakai sapaan, misalnya mbak atau nama panggilan agar terkesan ramah. Jadi, tuturan (3) berdasarkan skala kesekawanan masih berada pada tingkat kesantunan yang rendah.

\section{b. Skala Kesantunan Direktif Berdasarkan Strategi Tak Langsung}

Skala kesantunan direktif berdasarkan strategi tak langsung pada tingkat kesantunan rendah ditemukan 6 data, yaitu data 03 kategori kategori meminta, data 02, 13, dan 17 kategori mendesak, data 07 kategori memohon, dan data 12 kategori menyindir. Adapun pada tingkat kesantunan sedang terdapat 7 data, yaitu data 25 dan 26 kategori meminta, data 1 dan 23 kategori memerintah, data 15 kategori memohon, data 16 kategori menyindir, dan data 30 kategori memberi saran. Sementara itu, pada tingkat kesantunan baik ditemukan 6 data, data 05 kategori meminta, data 14, 24, dan 27 kategori mengharap, data 09 kategori merayu, dan data 10 kategori membujuk.

Cuplikan karakteristik skala kesantunan oleh mahasiswa Riau di lingkungan masyarakat berlatar belakang budaya Jawa pada contoh (4) menggunakan strategi tak langsung kategori meminta memiliki tingkat kesantunan yang baik sebagai berikut.

Tuturan (4) : Bisa bantu ndak? Temani aku makan ya? (Bisa bantu tidak? Temani saya makan ya?)

Konteks : Terjadi saat istirahat di kampus. $P n$ merasa lapar dan ingin $M t$ bisa menemaninya, meskipun $M t$ tidak ingin makan. Pn sebaya dengan $M t$. Akhirnya $M t$ mau menemani $P n$.

Ditinjau dari skala formalitas, tuturan (4) tampak tidak memaksa ditandai dari intonasi interogatif untuk hal meminta. Dengan demikian, Pn tidak terlihat memaksa Mt untuk menemaninya makan sehingga Mt akan merasa nyaman dengan ajakan Pn. Tuturan (4) meski disampaikan dengan strategi langsung, tetapi jika memenuhi skala formalitas dapat disimpulkan memiliki tingkat kesantunan yang baik.

Tuturan (4) juga menunjukkan bahwa Pn memberikan pilihan kepada Mt, yakni memberikan pilihan bisa bantu tidak. Dikaitkan dengan skala ketidaktegasan atau pilihan, maka tuturan tersebut menimbulkan tuturan menjadi tidak kaku atau tegang karena ada alternatif pilihan dalam tuturan. Tuturan (4) memiliki tingkat kesantunan yang baik.

Berdasarkan skala kesekawanan, tuturan (4) sudah menunjukkan rasa persahabatan. Pn terihat ramah karena Mt akhirnya mau menemani Pn. Keramahan Pn tampak dari tuturan meminta secara langsung dengan interogatif, yakni temani aku ya?. Jadi, tuturan tersebut dikatakan memiliki kesantunan yang baik. Hasil penelitian dari skala kesantunan dapat dilustrasikan melalui tabel 2 dan gambar 2 berikut. 
Tabel 2

Skala Kesantunan Direktif Mahasiswa Riau di Lingkungan Masyarakat Berlatar Belakang Budaya Jawa

\begin{tabular}{|c|c|c|c|c|c|}
\hline Jenis & Kategori & $\begin{array}{l}\text { Tingkat } \\
\text { Kesantunan } \\
\text { Rendah }\end{array}$ & $\begin{array}{c}\text { Tingkat } \\
\text { Kesantunan } \\
\text { Sedang }\end{array}$ & $\begin{array}{c}\text { Tingkat } \\
\text { Kesantunan } \\
\text { Baik }\end{array}$ & Frekuensi \\
\hline \multirow{6}{*}{$\begin{array}{l}\text { Skala } \\
\text { Kesantunan } \\
\text { Direktif } \\
\text { Berdasarkan } \\
\text { Strategi } \\
\text { Langsung }\end{array}$} & Mengajak & (6) & - & - & 1 \\
\hline & Meminta & $(20),(28)$ & - & (22) & 3 \\
\hline & Memerintah & $(4),(8)$ & - & & 2 \\
\hline & Mengingatkan & & - & (10) & 1 \\
\hline & Melarang & $(18),(21),(29)$ & - & & 3 \\
\hline & Menyilakan & & - & (19) & 1 \\
\hline \multicolumn{2}{|l|}{ Subtotal } & 8 data & - & 3 data & 11 data \\
\hline \multicolumn{2}{|c|}{ Persentase $\%=\underbrace{\text { Jumlah data }}_{\text {Jumlah total data }} \times 100 \%$} & $26,7 \%$ & $0 \%$ & $10 \%$ & \\
\hline \multirow{9}{*}{$\begin{array}{l}\text { Skala } \\
\text { Kesantunan } \\
\text { Direktif } \\
\text { Berdasarkan } \\
\text { Strategi Tak } \\
\text { Langsung }\end{array}$} & Meminta & (3) & $(25),(26)$ & (5) & 5 \\
\hline & Memerintah & & $(1),(23)$ & & 2 \\
\hline & Mendesak & $(2,(13,(17)$ & & & 3 \\
\hline & Memohon & (7) & $(15)$ & & 2 \\
\hline & Menyindir & (12) & (16) & & 2 \\
\hline & Mengharap & & & $(14),(24),(27)$ & 3 \\
\hline & Merayu & & & & 1 \\
\hline & Membujuk & & & (9) & 1 \\
\hline & Memberi saran & & $(30)$ & (10) & 1 \\
\hline \multicolumn{2}{|l|}{ Subtotal } & 6 data & 7 data & 6 data & 20 data \\
\hline \multicolumn{2}{|c|}{ Persentase $\%=\underset{\text { Jumlah total data }}{\text { Jumlah data }} \times 100 \%$} & $20 \%$ & $23,3 \%$ & $20 \%$ & \\
\hline \multicolumn{2}{|c|}{ Jumlah Total } & 14 data & 7 data & 9 data & 30 data \\
\hline \multicolumn{2}{|c|}{ Persentase Total } & $46,7 \%$ & $23,3 \%$ & $30 \%$ & $100 \%$ \\
\hline
\end{tabular}

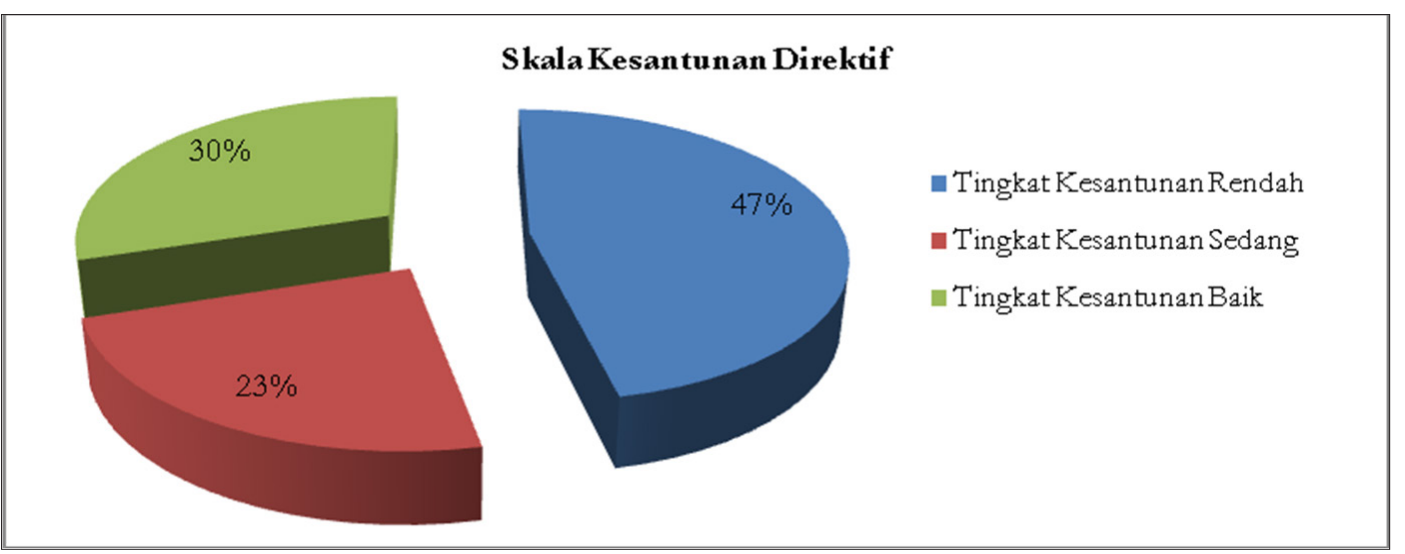

Gambar 2

Skala Kesantunan Direktif Mahasiswa Riau di Lingkungan Masyarakat Berlatar Belakang Budaya Jawa

Klasifikasi skala kesantunan direktif berdasarkan strategi langsung dan tak langsung pada tingkat kesantunan menunjukkan bahwa tidak semua penggunaan strategi langsung yang digunakan mahasiswa Riau berpotensi tidak santun. Sebaliknya, tidak semua penggunaan 
strategi tak langsung berpotensi santun. Namun, untuk menentukan simpulan tingkat kesantunan mahasiswa Riau di lingkungan masyarakar berlatar belakang budaya Jawa ditentukan dengan hasil keseluruhan penggunaan strategi langsung dan tak langsung.

Hasil penelitian mengenai skala kesantunan pernah diteliti oleh penelitian terdahulu, seperti yang dilakukan oleh Prayitno (2011) dan Musfifah (2012). Penelitian Prayitno (2011) berjudul "Teknik dan Strategi Tindak Kesantunan Direktif di Kalangan Andik SD Berlatar Belakang Budaya Jawa". Hasil penelitian Prayitno (2011) menyimpulkan bahwa skala tindak kesantunan direktif di kalangan andik SD berlatar belakang budaya Jawa lebih dibangun dengan skala untung-rugi dan langsung-tak langsung sehingga kurang menjangkau hal-hal bernilai skala pilihan. Perbedaan dengan penelitian ini terletak pada acuan analisis skala kesantunannya. Penelitian Prayitno (2011) mengkaji penggunaan skala pada tuturan direktif andik SD, sedangkan penelitian ini dengan mengacu skala kesantunan direktif akan menghasilkan potensi tingkat kesantunan mahasiswa Riau di lingkungan masyarakat berlatar belakang budaya Jawa.

Penelitian Masfufah (2012) mengkaji penelitian berjudul "Skala Kesantunan Bentuk Tuturan Direktif Berdasarkan Persepsi Siswa di SMAN 1 Surakarta”. Berdasarkan hasil penelitian diperoleh simpulan bahwa urutan atau peringkat kesantunan bentuk tuturan direktif berdasarkan persepsi siswa SMAN 1 Surakarta dari bentuk yang paling santun sampai yang tidak santun. Keterkaitan penelitian Masfufah (2012) dengan penelitian ini tampak bahwa untuk menentukan tingkat kesantunan digunakannya skala kesantunan. Namun, penelitian Masfufah (2012) untuk menentukan skala kesantunan ditentukan dari bentuk kuesioner dari persepsi siswa, sedangkan penelitian ini dianalisis berdasarkan tuturan direktif dan ditinjau berdasarkan skala kesantunan Lakoff.

\section{Implikasi terhadap Pembelajaran Bahasa secara Santun di SMA}

Penelitian ini mengkaji adanya kesantunan berbahasa. Ngalim (2013:78) menyatakan bahwa tujuan mempelajari kesantunan berbahasa ialah bagaimana kesantunan didefinisikan sebagai wujud komunikasi yang respek terhadap hubungan antara penutur dengan mitra tutur sehingga penggunaan strategi komunikasi dikenal oleh masyarakat sebagai sebuah kekuatan penuturan yang sekaligus dilakukan secara khusus. Sehubungan dengan itu, penelitian ini dapat berimplikasi pada proses pembelajaran bahasa Indonesia di lembaga pendidikan, seperti di sekolah menengah atas atau SMA. Kesantunan berbahasa dapat menciptakan pembelajaran yang menyenangkan sehingga terjadi komunikasi yang baik.

Hasil penelitian ini dapat diimplikasikan pada pembelajaran di sekolah SMA yang terdapat materi ajar berkaitan dengan kesantunan berbahasa, seperti materi bernegosiasi dalam perundingan, memaparkan pendapat, menyampaikan paparan atau penjelasan, cerita, berita, dll. Implikasi penelitian ini tampak pada kurikulum 2013, yaitu kompetensi inti-2 (KI-2) untuk sikap sosial dari kelas X, XI, dan XII yang menuntut siswa mampu menggunakan bahasa Indonesia dengan santun pada proses pembelajaran. Contohnya adalah implikasi pada materi kelas X pada KI-2 dengan KD 2.4, yaitu menunjukkan perilaku jujur, disiplin, peduli, dan santun dalam menggunakan bahasa Indonesia untuk bernegosiasi dalam perundingan, materi kelas XI pada KI-2 dengan KD 2.4, yaitu menunjukkan perilaku jujur, disiplin, peduli, dan santun dalam menggunakan bahasa Indonesia untuk menyampaikan paparan, dan materi kelas XII pada K1-2 dengan KD 2.1, yaitu menunjukkan perilaku jujur, responsif, dan santun dalam menggunakan bahasa Indonesia untuk menyampaikan cerita sejarah tentang tokoh-tokoh nasional dan internasional. Adapun pada kurikulum KTSP dapat diimplikasikan pada standar kompetensi keterampilan berbicara, misalnya materi kelas X dengan KD 2. Mengungkapkan pikiran, perasaan, dan informasi melalui kegiatan berkenalan, berdiskusi, dan bercerita, materi 
kelas XI KD 2. Mengungkapkan secara lisan informasi hasil membaca dan wawancara, dan materi kelas XII dengan KD 2. Mengungkapkan gagasan, tanggapan, dan informasi dalam diskusi,

Penelitian ini yang mengkaji kesantunan tindak direktif dapat diimplikasi pada penjabaran materi tersebut. Siswa tidak akan terlepas dari penggunaan bahasa tindak direktif. Dengan demikian, analisis strategi dan skala kesantunan tindak direktif mahasiswa Riau di lingkungan masyarakat berlatar belakang budaya Jawa bisa menjadi referensi bahan ajar di SMA. Pembelajaran menjadi menyenangkan jika siswa dan guru dapat menggunakan bahasa yang santun. Siswa dan guru akan memahami tuturan direktif yang santun atau tidak santun dengan alasan yang sudah dijelaskan dalam penelitian berdasarkan acuan yang digunakan peneliti. Siswa dan guru diharapkan mampu menggunakan strategi bertutur yang tepat dalam proses pembelajaran. Penggunaan strategi bertutur yang tepat dapat menciptakan komunikasi yang baik dan efektif serta memberikan rasa nyaman dan menyenangkan.

\section{SIMPULAN}

Penggunaan strategi kesantunan direktif dalam penelitian ini terdiri dari dua jenis, yaitu strategi langsung dan strategi tak langsung. Hasil temuan penelitian ini menunjukkan bahwa mahasiswa Riau ketika bertutur dengan masyarakar berlatar belakang budaya Jawa lebih banyak menggunakan cara-cara tak langsung daripada cara langsung. Perbandingan antara strategi perwujudan kategori tak langsung dengan langsung (63,3\%:36,70\%).

Kombinasi strategi kesantunan dengan skala kesantunan yang digunakan mahasiswa Riau di lingkungan masyarakat berlatar belakang budaya Jawa dapat dikemukakan bahwa mahasiswa Riau memiliki tingkat kesantunan yang rendah dengan perbandingan $(47 \%: 23 \%$ : $30 \%$ ). Total data pada skala kesantunan direktif berdasarkan strategi langsung dan tak langsung untuk tingkat kesantunan rendah sebanyak 14 data, tingkat kesantunan sedang sebanyak 7 data, dan tingkat kesantunan baik sebanyak 9 data. Dari uraian di atas dapat dipetik bahwa mahasiswa Riau di lingkungan masyarakat berlatar belakang budaya Jawa masih memerlukan bimbingan bernilai positif dan santun agar tercipta kerukunan dan keharmonisan.

Penelitian ini yang mengkaji kesantunan tindak direktif dapat diimplikasi pada penjabaran materi tersebut. Siswa tidak akan terlepas dari penggunaan bahasa tindak direktif. Dengan demikian, analisis strategi dan skala kesantunan tindak direktif mahasiswa Riau di lingkungan masyarakat berlatar belakang budaya Jawa bisa menjadi referensi bahan ajar di SMA. Implikasi penelitian ini tampak pada kurikulum 2013, yaitu kompetensi inti-2 (KI-2) untuk sikap sosial dari kelas X, XI, dan XII yang menuntut siswa mampu menggunakan bahasa Indonesia dengan santun pada proses pembelajaran. Misalnya, materi kelas X pada KI-2 dengan KD 2.4, yaitu menunjukkan perilaku jujur, disiplin, peduli, dan santun dalam menggunakan bahasa Indonesia untuk bernegosiasi dalam perundingan. Adapun pada kurikulum KTSP dapat diimplikasikan pada standar kompetensi keterampilan berbicara, misalnya materi kelas X dengan KD 2 . Mengungkapkan pikiran, perasaan, dan informasi melalui kegiatan berkenalan, berdiskusi, dan bercerita. Penggunaan strategi bertutur yang tepat dapat menciptakan komunikasi yang baik dan efektif serta memberikan rasa nyaman dan menyenangkan terutama dalam proses pembelajaran.

\section{PERSANTUNAN}

Ucapan terima kasih penulis sampaikan kepada Prof. Dr. Harun Joko Prayitno, M. Hum. yang telah berkenan menjadi pembimbing dalam penelitian ini. 


\section{DAFTAR PUSTAKA}

Aliakbari, Mohammad. 2015. "Variation of Politeness Strategies among the Iranian Students" dalam Journal Internasional Theory and Practice in Language Study, Vol. 5, No.5, hal: 981-988. Iran: Ilam University.

Andianto, Mujimas Rus, dkk. 2012. "Merekontruksi Model Strategi Kesantunan Berbahasa Kompromitif Madura-Jawa untuk Referensi Pendidikan Etika Lintas Kultur" dalam Laporan Penelitian Hibah Stranas Bidang Ilmu Humaniora. Jember: Universitas Jember.

Anwari, dkk. 2013. "Tindak Tutur Direktif pada Proses Pembelajaran Bahasa Indonesia di Kelas X" dalam Jurnal J-Simbol Pendidikan Bahasa dan Sastra Indonesia, Vol. 1, No. 1, hal. 1-12. Lampung: Universitas Lampung.

Bacha, Nahla Nola. 2012. "Gender and Politeness in a Foreign Language Akademic Contexs" dalam International Journal of English Linguistic, Vol. 2, No. 1, hal. 79-96. Lebanon: Lebanese American University.

Chaer, Abdul. 2010. Kesantunan Berbahasa. Jakarta: Rineka Cipta.

Gu, Tongqing. 2014. "A Study: Based Study on the Performance of the Suggestion Speech Act by Chinese EFL Learners" dalam International Journal of English Linguistics, Vol. 4, No.1, hal. 103-111. China: China West Normal University.

Maros, Marlyna. 2011. "Strategi Kesantunan Melayu dalam Membuat Teguran” dalam Jurnal Elektronik Jabatan Bahasa dan Kebudayaan Melayu, Jilid 3, hal. 7-20. Malaysia: Universitas Kebangsaan Malaysia.

Masfufah, Nurul. 2012. "Skala Kesantunan Bentuk Tuturan Direktif Berdasarkan Persepsi Siswa SMAN 1 Surakarta" dalam Jurnal Kajian Linguistik dan Sastra, Vol. 24, No. 2, hal. 199-214. Surakarta: Universitas Sebelas Maret.

$\mathrm{Mu}$, Yuting. 2015. "Application of Politeness Strategies in English and Chinese Movie Reviews" dalam International Journal of English Linguistic, Vol. 5, No. 6, hal. 105-114. China: Shandong Vocational College of Foreign Affairs Translation.

Ngalim, Abdul. 2013. Sosiolinguistik: Suatu Kajian Fungsional dan Analisisnya. PBSID FKIP UMS: Solo.

Nadar, F.X. 2009. Pragmatik dan Penelitian Pragmatik. Yogyakarta: Graha Ilmu.

Peng, Liu. 2014. "A Case Study of College Teacher's Politeness Strategy in EFL Classroom” dalam Journal Internasional Theory and Practice in Language Study, Vol. 4, No.1, hal: 110-115, China: Sichuan University of Science and Tehcnology.

Pramuaniati, Isda dan Evy Eviyanti. 2012. "Perilaku Berbahasa pada Penentuan Strategi Tindak Tutur Melarang Penutur Bahasa Aceh Dialek Aceh Utara" dalam Prosiding Seminar Nasional "Bahasa dalam Prespektif Globalisasi", hal. 205-211, tanggal 26-27 September. Bengkulu: Universitas Bengkulu.

Prayitno, Harun Joko. 2010. "Perwujudan Prinsip Kerja Sama, Sopan santun, dan Ironi Para Pejabat dalam Peristiwa Rapat Dinas di Lingkungan Pemrintahan Kota Berbudaya Jawa" dalam Jurnal Terakreditasi Kajian Linguistik dan Sastra, Volume 21, No. 2, Desember 2010, Jurusan Pendidikan Bahasa Inggris dan Indonesia FKIP UMS.

-------. 2011. "Teknik dan Strategi Tindak Kesantunan Direktif di Kalangan Andik SD Berlatar Belakang Budaya Jawa" dalam Kajian Linguistik dan Sastra, Vol. 23, No. 2, Desember 
2011: 204: 218 .

- 2011. Kesantunan Sosiopragmatik: Studi Pemakaian Tindak Direktif di Kalangan Andik SD Berbudaya Jawa. Surakarta: Muhammadiyah University Press.

Rahardi, Kunjana.2005. Pragmatik: Kesantunan Imperatif Bahasa Indonesia. Jakarta: Erlangga.

Sudaryanto. 1993. Metode dan Aneka Teknik Analisis Bahasa: Pengantar Penelitian Wahana Kebudayaan secara Linguistis. Yogyakarta: Duta Wacana University Press.

Sukma, Fiky Reustia, dkk. 2012. "Kesantunan Berbahasa Minangkabau dalam Tindak Tutur Menyuruh di Kenagarian Tambang Kecamatan IV Jurai Kabupaten Pesisir Selatan" dalam Jurnal Pendidikan Bahasa dan Sastra Indonesia, Volume 1, No. 1, Seri G: 515-599. Padang: Universitas Negeri Padang.

Sulistyowati, Rini Indah. 2013. "Perilaku Tindak Tutur Ustad dalam Pengajian: Kajian Sosiopragmatik dengan Pendekatan Bilingual" dalam Jurnal Penelitian Humaniora, Volume 14, Nomor 1, Februari 2013:25-45. Surakarta: Universitas Muhammadiyah Surakarta.

Welvi, Yossie Ana, dkk. 2015. "Tindak Tutur Direktif Guru dalam Proses Pembelajaran di MTs Riadhus Sholihin Koto Baru Kabupaten Sijunjung" dalam Jurnal Pendidikan Bahasa, Sastra, dan Pembelajaran, Vol. 3, No. 1, hal. 84-95. Padang: Universitas Negeri Padang. 